\title{
APAKAH THINK-PAIR-SHARE DAPAT MENGURANGI KECEMASAN MATEMATIKA SISWA SMP?
}

\author{
${ }^{1}$ Yosepha Patricia Wua Laja ${ }^{*}{ }^{2}$ Heri Retnawati \\ 1. Pendidikan Matematika Universitas Timor, 2. PPs Pendidikan Matematika \\ Universitas Negeri Yogyakarta \\ *dianlaja1117@gmail.com
}

Diterima: Juli 2019. Disetujui: September 2019. Dipublikasikan: November 2019

\begin{abstract}
ABSTRAK
Kecemasan yang dialami para siswa dapat mempengaruhi bagaimana siswa tersebut berpikir, bertindak dan berhubungan dengan pelajaran matematika. Salah satu solusi yang digunakan untuk mengurangi kecemasan matematika siswa adalah dengan menerapkan suatu teknik pembelajaran kooperatif think-pair-share. Teknik ini diawali dengan berpikir tentang jawaban atas pertanyaan yang diajukan oleh guru, berpasangan untuk mendiskusikan jawaban dan berbagi dalam kelompok yang lebih besar. Oleh karena itu, tujuan penelitian ini untuk melihat apakah teknik think-pair-share dapat mengurangi kecemasan matematika siswa SMP. Penelitian ini merupakan penelitian tindakan kelas model spiral Kemmis dan Tanggart yang terdiri dari dua siklus dengan tahap awal menyusun target pencapaian indicator keberhasilan penelitian. Hasil penelitian menunjukan bahwa rata-rata kecemasan siswa pada kondisi awal sebesar 96 (Tinggi), kemudian menurun menjadi 85 (Tinggi) pada siklus I dan 73 (Sedang) di akhir siklus II. Sedangkan presentase keterlaksanaan pembelajaran dengan teknik think-pair-share pada akhir siklus I sebesar 75,5\% dan pada akhir siklus II sebesar 87\%. Hal ini mengindikasikan bahwa dengan memberikan tindakan berbagi jawaban dan menjelaskan di depan kelas bersama pasangan kepada teman-teman lain pada penerapan pembelajaran kooperatif teknik think-pair-share dapat mengurangi kecemasan matematika siswa SMP.
\end{abstract}

Kata kunci: think-pair-share, kecemasan matematika, penelitian tindakan kelas

\begin{abstract}
The students feel anxious so that the anxiety affects how they think, act and deal with mathematics. One of solutions which can be used to reduce students' math anxiety is by applying a cooperative learning technique, think-pair-share. This technique began by thinking about the answer of a question posed by teacher, discussing the answer in pairs and sharing it to the bigger group. The purpose of the study was to find out whether think-pair-share technique can reduce the math anxiety of Junior High School students. This was a classroom action research with Kemmis and Tanggart spiral model. It consisted of two cycles with the initial stage was arranging the achievement target of research success indicator. The research result indicated that the mean of students' anxiety at the initial condition was 96 (high), then it was reduced to 85 (high) in cycle I and 73 (moderate) at the end of cycle II. While the precentage of learning implementation with think-pair-share technique at the end of cycle I was $75,5 \%$ and at the end of cycle II was $87 \%$. This indicated that by giving treatment of sharing answer and explaining it in front of the class with the team mate to the other friends on the implementation of think-pair-share cooperative learning technique can reduce the math anxiety of Junior High School students.
\end{abstract}

Keywords: think-pair-share, math anxiety, classroom action research

\section{Pendahuluan}

Matematika sebagai salah satu mata pelajaran yang wajib dipelajari karena peran matematika sangat penting dalam segala hal misalnya adanya transaksi jual beli dalam kehidupan sehari-hari, adanya perkiraan tentang suatu kondisi tertentu, adanya perhitungan waktu dan jarak suatu daerah dengan daerah lain serta peran matematika lainnya. Namun, berdasarkan sumber nasional Indonesia 
tahun 2015, 2016 dan 2017 hasil ujian nasional matematika di Indonesia dalam tiga tahun terakhir paling rendah dibandingkan mata pelajaran lainnya.

Persoalan rendahnya nilai matematika ini dipengaruhi oleh beberapa faktor internal maupun faktor eksternal. Salah satu faktor internal yang menyebabkan rendahnya prestasi matematika adalah tingginya rasa kecemasan pada diri siswa (Saputra, 2014: 75). Hal ini sejalan dengan hasil penelitian yang dilakukan Zakaria \& Nordin (2008: 27) yang mengemukakan bahwa prestasi dan kecemasan matematika memiliki korelasi yang negatif. Artinya siswa dengan kecemasan yang tinggi memiliki prestasi yang rendah, demikian pula sebaliknya. Selain itu, Norwood (1981: 248) mengungkapkan bahwa siswa dengan kecemasan matematika tinggi lebih nyaman mengerjakan tugas matematika tanpa algoritma yang baik yang dapat mempengaruhi prestasi belajar siswa tersebut. Beberapa penelitian telah menunjukkan bahwa rasa kecemasan matematika pada siswa memang dirasakan khususnya siswa SMP (M.Puteh \& S. Z.Khalin, 2016: 119, . J. Dindyal, L. P. Cheng \& S. F. Ng, 2012: 570 ).

Kecemasan merupakan suatu perkara yang dialami oleh seseorang baik orang dewasa maupun anak-anak yang dapat mempengaruhi bagaimana seseorang dapat berpikir, bertindak/berperilaku, merasa dan berhubungan dengan orang lain (Elliot \& Smith, 2006: 147). Kecemasan matematika yang dirasakan oleh siswa akan mempengaruhi bagaimana siswa tersebut berpikir, bertindak dan berhubungan dengan pelajaran matematika. Lebih lanjut, Haylock \& Thangata (2007: 12) mengungkapkan bahwa kecemasan terhadap matematika tampak dalam berbagai cara. Mulai dari kepanikan siswa ketika dihadapkan dengan tugas matematika dan tidak dapat berpikir jernih dalam mengingat hal-hal yang mereka tahu dan bisa lakukan. Berdasarkan hasil wawancara beberapa siswa di salah satu SMP di Yogyakarta memiliki kecemasan tergolong dalam kategori sangat tinggi. Hal ini ditunjukkan dari respon siswa ketika diberikan tugas berupa soal matematika siswa tersebut merasa khawatir mendapatkan jawaban yang salah sehingga siswa tersebut tidak ingin mengerjakan soal matematika di depan kelas. Selain itu, beberapa siswa memiliki keyakinan bahwa mereka tidak dapat mengerjakan dengan baik dalam setiap jenis tes matematika dan mereka yakin bahwa mereka tidak bisa mengerti sehingga mengandalkan menghafal aturan bukan pada pemahaman.

Bukti empiris dari dari hasil angket kecemasan yang telah disebarkan diperoleh bahwa 39,13\% dari total 23 siswa memiliki rasa kecemasan yang sangat tinggi terhadap matematika, 8,69\% siswa memiliki rasa kecemasan tinggi dan 17,39\% siswa memiliki rasa kecemasan yang sedang terhadap matematika dan $21,73 \%$ siswa memiliki rasa kecemasan yang sangat rendah. Data tersebut disajikan pada tabel berikut:

Tabel 1. Hasil Observasi Pra-penelitian Angket Kecemasan Matematika Siswa

\begin{tabular}{ccc}
\hline Interval & Kriteria & Kondisi Awal \\
\hline $\mathrm{X}>100$ & Sangat Tinggi & $39,13 \%$ \\
\hline $83,33<\mathrm{X} \leq 100$ & Tinggi & $8,69 \%$ \\
\hline $66,67<\mathrm{X} \leq 83,33$ & Sedang & $17,39 \%$ \\
\hline $50<\mathrm{X} \leq 66,67$ & Rendah & $13,04 \%$ \\
\hline $\mathrm{X} \leq 50$ & Sangat Rendah & $21,73 \%$ \\
\hline Rata-Rata & $96 \%$ & Tinggi \\
\hline
\end{tabular}

(Ebel \& Frisbie, 1991: 280)

Artinya lebih dari $96 \%$ dari total 23 siswa di kelas tersebut memiliki tingkat kecemasan yang tinggi terhadap matematika. Woodard (2004: 3) mengungkapkan bahwa salah satu cara mengatasi kecemasan matematika adalah dengan membelajarkan matematika menggunakan metode kooperatif yang bisa mengakomodir berbagai model belajar siswa. Sejalan dengan pendapatnya Woodard, Titsankaew, Pichaya (2015: 83) mengungkapkan bahwa belajar melalui pembelajaran yang kooperatif, siswa dapat enjoy dalam bereksperimen dengan matematika, mengeksplore kemampuannya bersama teman-temannya, saling bertukar pikiran bersama teman-temannya. Sehingga siswa tidak hanya berpikir bahwa matematika hanyalah sekumpulan rumus dan prosedur.

Salah satu metode pembelajaran kooperatif yang dapat digunakan adalah Think Pair Share (TPS). Pembelajaran kooperatif dengan teknik think-pair-share adalah strategi belajar aktif yang diyakini mampu mengoptimalkan siswa dalam pembelajaran melalui berpikir tentang jawaban atas pertanyaan yang diajukan oleh guru, berpasangan untuk mendiskusikan jawaban dan berbagi dalam kelompok yang lebih besar (Arends \& Kilcher, 2010: 174, Kothiyal, $d k k$, 2013). TPS sebagai 


\section{Jurnal Pendidikan Matematika Vol 1 No 1 Tahun 2019 Yosepha Patricia Wua Laja}

pembelajaran kooperatif diyakini dapat diterapkan sebagai alternatif seting pembelajaran yang membuat siswa senang, merangsang aktivitas siswa untuk berpikir, mendiskusikan hasil pemikirannya dengan teman dan merangsang keberanian siswa untuk mengemukakan pendapatnya di depan kelas sehingga tingkat kecemasan matematika siswa dapat diminimalkan ataupun dihilangkan. Oleh karena itu, tujuan penelitian ini untuk mengetahui apakah teknik kooperatif think-pair-share dapat mengurangi kecemasan matematika siswa SMP.

\section{Kajian Literatur}

\section{Kecemasan Matematika}

Zeidner \& Matthews (2011: 9) memandang kecemasan sebagai serangkaian aspek multidimensi yang kompleks yang terbentuk dari dimensi kognitif, afektif, somatik dan reaksi perilaku. Pada gangguan berpikir (kognitif) siswa sering khawatir tentang masalah dalam proses kognitif meliputi meningkatnya kesadaran ancaman, dan memfokuskan perhatianya pada kemungkinan adanya bahaya. Sedangkan pada gangguan emosi negatif (afektif) ditunjukan dengan adanya perasaan kecemasan sebagai emosi dan suasana, misalnya merasa tegang, gugup dan gelisah. Selain itu, gangguan somatik ditunjukkan dengan adanya kecemasan seringkali disertai dengan gejala fisik, seperti jantung berdebar, telapak tangan berkeringat, tubuh merespon ancaman dengan mempersiapkan untuk melawan atau menghindari. Sedangkan gangguan perilaku ditandai dengan adanya kecemasan dengan berusaha melarikan diri dari bahaya dan kecemasan perilaku nonverbal seperti gelisah.

Lebih lanjut Haylock \& Thangata (2007: 12) juga mengungkapkan bahwa kecemasan membuat siswa memiliki perasaan takut ketika berhadapan dengan tugas matematika dan khawatir berlebihan tentang mendapatkan jawaban yang salah. Siswa mengembangkan keyakinan bahwa mereka tidak dapat mengerjakan dengan baik dalam setiap jenis tes matematika dan mereka yakin mereka tidak bisa mengerti sehingga mengandalkan menghafal aturan bukan pada pemahaman.

\section{Think Pair Share}

Arends \& Kilcher (2010: 247) mengungkapkan langkah-langkah dalam pembelajaran kooperatif think-pair-share adalah : [1] Thinking (Berpikir) ;Guru mengajukan sebuah pertanyaan atau isu yang berkaitan dengan pelajaran dan meminta setiap siswa menggunakan waktu beberapa menit untuk memikirkan jawaban mereka secara mandiri atas pertanyaan tersebut; [2] Pairing (Berpasangan); Siswa diminta berpasangan untuk mendiskusikan apa yang telah dipikirkan pada tahap pertama. 4-5 menit adalah waktu normal yang dipakai untuk tahap ini. Interaksi yang diharapkan pada tahap ini adalah siswa dapat mengindentifikasi masalah yang diberikan oleh guru; [3] Sharing (Berbagi); Guru meminta beberapa siswa untuk berbagi dengan seluruh kelas atas apa yang telah mereka bahas.

\section{Metodologi}

Penelitian ini merupakan penelitian tindakan kelas. Penelitian tindakan kelas efektif digunakan sebab dapat memperbaiki cara pengajaran, dapat menyediakan sarana untuk mendokumentasikan keefektifan pengajaran memberi semangat baru untuk mengenalkan metode pengajaran yang baru (J, 1993: 570). PTK ini menggunakan model spiral Kemmis dan Tanggart (Kusumah, Wijaya dan Dedi, 2010 :20). Penelitian tindakan kelas dilaksanakan sekurang-kurangnya terdiri dari dua siklus dan masing-masing menggunakan empat komponen tindakan yaitu: perencanaan (planning), tindakan $(a c t)$, pengamatan (observing) dan refleksi (reflecting). Penelitian ini terdiri dari dua siklus, namun jika hasil dari tiap siklus atau siklus terakhir belum memenuhi indikator keberhasilan yang telah ditetapkan, maka dilanjutkan untuk siklus berikutnya.

Instrumen pada penelitian ini mencakup lembar observasi, angket kecemasan matematika siswa dan tes yang berguna untuk mengetahui ketercapaian siswa dalam belajar dan menilai ketuntasan belajar siswa. Tes ini berupa soal pilihan ganda dan essay yang disusun berdasarkan indikator yang telah dibuat. Tes ini juga berupa pretest yang dilaksanakan sebelum tindakan siklus dilaksanakan dan posttest dilaksanakan setiap akhir siklus. 


\section{Hasil Penelitian dan Pembahasan}

Data hasil analisis keterlaksanaan pembelajaran yang dilakukan guru pada siklus I dan II dapat dilihat pada tabel 2 .

\begin{tabular}{cccc}
\multicolumn{3}{c}{ Tabel 2. Keterlaksanaan Pembelajaran Guru pada Siklus I dan II } \\
\hline Siklus & Pertemuan & $\begin{array}{c}\text { Rerata } \\
\text { Keterlaksanaan } \\
\text { Pembelajaran } \\
\text { Guru (\%) }\end{array}$ & Kategori \\
\hline Siklus I & Pertama & 76 & Baik \\
& Kedua & 84 & Sangat Baik \\
& Ketiga & 84 & Sangat Baik \\
& Keempat & 72 & Baik \\
\hline Siklus II & Pertama & 92 & Sangat Baik \\
& Kedua & 92 & Sangat Baik \\
\hline
\end{tabular}

Tabel 2 menunjukkan bahwa persentasi keterlaksanaan pembelajaran yang dilakukan guru pada siklus I pada pertemuan pertama, kedua, ketiga dan keempat berada pada ketegori baik dan sangat baik. Pada siklus II untuk pertemuan pertama dan kedua berada pada kategori sangat baik. Sedangkan data hasil keterlaksanaan pembelajaran yang dilakukan siswa pada siklus I dan II dapat dilihat pada tabel 3.

Tabel 3. Keterlaksanaan pembelajaran pada siklus I dan II

\begin{tabular}{cccc}
\hline Siklus & Pertemuan & $\begin{array}{c}\text { Rerata } \\
\text { Keterlaksanaan } \\
\text { Pembelajaran } \\
\text { Siswa (\%) }\end{array}$ & Kategori \\
\hline Siklus I & Pertama & 76 & Baik \\
& Kedua & 72 & Baik \\
& Ketiga & 72 & Baik \\
& Keempat & 68 & Baik \\
\hline Siklus II & Pertama & 84 & Sangat Baik \\
& Kedua & 80 & Sangat Baik \\
\hline
\end{tabular}

Sedangkan keterlaksanaan pembelajaran yang dilakukan siswa pada siklus I dan II dapat dilihat pada tabel 3. Hasil analisis keterlaksanaan pembelajaran guru dan siswa pada siklus I dan II dapat dilihat pada gambar 1.

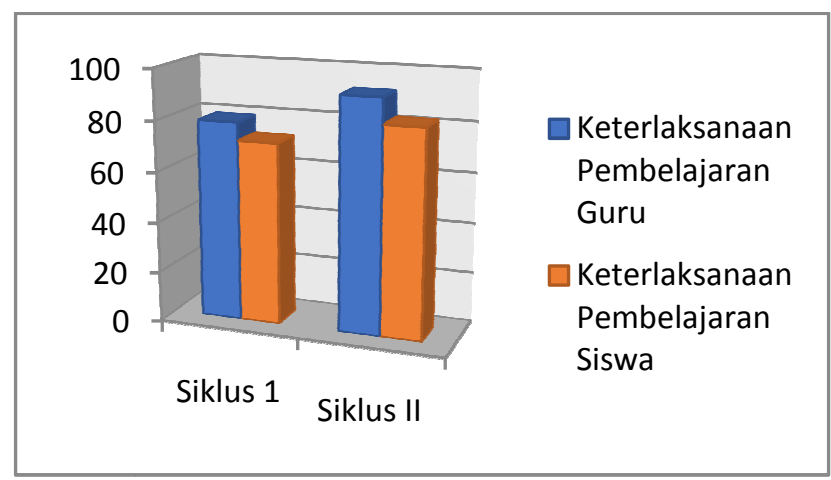

Gambar 1. Grafik Keterlaksanaan Pembelajaran Guru dan Siswa

Selain terjadi peningkatan aktivitas keterlaksanaan pembelajaran guru dan siswa, penerapan thinkpair-share dapat menurunkan tingkat kecemasan siswa pada siklus I dan II yang dapat dilihat pada tabel 4 dan 5. 


\section{Jurnal Pendidikan Matematika Vol 1 No 1 Tahun 2019 Yosepha Patricia Wua Laja}

Tabel 4. Kondisi Awal Sebelum Perlakuan

\begin{tabular}{|c|c|c|c|c|}
\hline Variabel & Interval & Kriteria & $\begin{array}{c}\text { Kondisi } \\
\text { Awal }\end{array}$ & Target \\
\hline \multirow[t]{6}{*}{ Kecemasan } & $X>100$ & $\begin{array}{l}\text { Sangat } \\
\text { Tinggi }\end{array}$ & $39,13 \%$ & $8,69 \%$ \\
\hline & $83,33<X \leq 100$ & Tinggi & $8,69 \%$ & $4,34 \%$ \\
\hline & $\begin{array}{l}66,67<X \\
\leq 83,33\end{array}$ & Sedang & $17,39 \%$ & $30,43 \%$ \\
\hline & $50<X \leq 66,67$ & Rendah & $13,04 \%$ & $39,13 \%$ \\
\hline & $X \leq 50$ & $\begin{array}{l}\text { Sangat } \\
\text { Rendah }\end{array}$ & $21,73 \%$ & $17,39 \%$ \\
\hline & Rata-rata & & 96 (Tinggi) & Rendah \\
\hline $\begin{array}{c}\text { Kognitif } \\
\text { Pembelajaran }\end{array}$ & $\begin{array}{c}\text { Ketuntasan } \geq 75 \\
\%\end{array}$ & $\begin{array}{c}\text { KKM } \\
\text { Tercapai } \\
\end{array}$ & $0 \%$ & $75 \%$ \\
\hline $\begin{array}{c}\text { Proses } \\
\text { Pembelajaran }\end{array}$ & $\begin{array}{c}\text { Terlaksana } \geq 80 \\
\%\end{array}$ & $\begin{array}{c}\text { Pembelajaran } \\
\text { Berhasil } \\
\end{array}$ & & $85 \%$ \\
\hline
\end{tabular}

Tabel 5. Kondisi Pembelajaran Setelah Siklus I dan Siklus II

\begin{tabular}{|c|c|c|c|c|}
\hline Variabel & Interval & Kriteria & $\begin{array}{l}\text { Akhir } \\
\text { Siklus I }\end{array}$ & $\begin{array}{c}\text { Akhir Siklus } \\
\text { II }\end{array}$ \\
\hline \multirow[t]{6}{*}{ Kecemasan } & $X>100$ & Sangat Tinggi & $21,73 \%$ & $13,04 \%$ \\
\hline & $83,33<X \leq 100$ & Tinggi & $8,69 \%$ & $6,34 \%$ \\
\hline & $\begin{array}{l}66,67<\mathrm{X} \\
\leq 83,33\end{array}$ & Sedang & $17,39 \%$ & $30,43 \%$ \\
\hline & $50<X \leq 66,67$ & Rendah & $21,73 \%$ & $28,43 \%$ \\
\hline & $X \leq 50$ & $\begin{array}{l}\text { Sangat } \\
\text { Rendah }\end{array}$ & $30,43 \%$ & $21,73 \%$ \\
\hline & Rata-rata & & 85 (Tinggi) & 73(Sedang) \\
\hline $\begin{array}{c}\text { Kognitif } \\
\text { Pembelajaran } \\
\end{array}$ & $\begin{array}{c}\text { Ketuntasan } \geq 75 \\
\%\end{array}$ & $\begin{array}{c}\text { KKM } \\
\text { Tercapai } \\
\end{array}$ & $60,86 \%$ & $75,21 \%$ \\
\hline $\begin{array}{c}\text { Proses } \\
\text { Pembelajaran }\end{array}$ & $\begin{array}{c}\text { Terlaksana } \geq 80 \\
\%\end{array}$ & $\begin{array}{c}\text { Pembelajaran } \\
\text { Berhasil }\end{array}$ & $75,5 \%$ & $87 \%$ \\
\hline
\end{tabular}

Berdasarkan observasi keterlaksanan pembelajaran, persentase keterlaksanaan pembelajaran untuk siklus I mencapai $75,5 \%$ \% sehingga keterlaksanaan pembelajaran dapat dikatakan belum berjalan optimal dan belum mencapai target pencapaian. Sedangkan untuk data kecemasan matematika siswa siklus pertama untuk kategori sangat tinggi menurun menjadi menjadi $21,73 \%$ dari kondisi awal 39,13\%, kemudian untuk kategori tinggi berada pada persentase 8,69\% dan kategori sedang berada pada persentase 17,39\% sedangkan kategori sangat rendah meningkat menjadi $30,43 \%$ dari kondisi awal 21,73\%. Penelitian ini bertujuan untuk mengurangi kecemasan siswa terhadap pembelajaran matematika sehingga peneliti menargetkan agar persentase siswa yang memiliki kecemasan sangat tinggi dan tinggi harus dikurangi.

Dilain pihak, keterlaksanaan pembelajaran pada siklus II mencapai $87 \%$ melampaui target yang ditetapkan sehingga dapat dikatakan permbelajaran berjalan optimal dan baik. Untuk data hasil angket kecemasan matematika siswa siklus II mengalami penurunan dari siklus pertama yaitu untuk kategori sangat tinggi menurun menjadi $13,04 \%$ dari siklus I sebesar $21,73 \%$, ketegori tinggi menurun menjadi $6,34 \%$ dari siklus I sebesar 8,69. Sedangkan untuk sedang meningkat menjadi $30,43 \%$ dari siklus I sebesar 17,39\%. Untuk kategori rendah meningkat menjadi $28,43 \%$ dari siklus I sebesar $21,73 \%$. Sedangkan untuk kategori sangat rendah menurun menjadi $21,73 \%$ dari siklus I sebesar $30,43 \%$.

Hasil penelitian menunjukkan penurunan rasa kecemasan matematika siswa dengan menggunakan teknik think-pair-share. Tindakan yang dilakukan pada pembelajaran kooperatif teknik 


\section{Jurnal Pendidikan Matematika Vol 1 No 1 Tahun 2019 Yosepha Patricia Wua Laja}

think-pair-share dapat berhasil karena guru mempersiapkan proses pembelajaran dengan baik dan tetap menjaga kondusif kelas. Kemudian masing-masing siswa diharuskan untuk berpikir mengenai jawaban dari suatu masalah matematika. Setelah siswa berpikir, siswa bersama pasangannya saling berbagi jawaban yang diberikan kemudian guru meminta siswa untuk berpasangan maju ke depan kelas menjelaskan jawaban yang mereka kerjakan. Ketika para siswa maju ke depan kelas, mereka maju tanpa merasa takut dan cemas karena mereka maju bersama pasangan kelompoknya. Hal ini sejalan dengan apa yang diungkapkan oleh Titsankaew, Pichaya (2015: 87) bahwa pembelajaran kooperative teknik think-pair-share memberikan kesempatan kepada para siswa untuk berpikir dalam mengemukakan sebuah hipotesis yang akan diselidiki, kemudian dengan berpasangan saling bertukar pendapat dan saling berbagi. Dengan teknik think-pair-share tercipta suasana kelas yang lebih rileks sehingga siswa merasa lebih enjoy dalam mempelajari matematika. Dengan begitu, rasa kecemasan siswa terhadap matematika menjadi berkurang. Dan faktor lainnya adalah sudah ada kedekatan yang dibangun antara guru dan siswa sehingga siswa tidak merasa sungkan atau malu selama proses pembelajaran. Penelitian yang telah dilaksanakan memiliki keterbatasan, antara lain:

a. Hasil penelitian ini hanya berlaku pada siswakelas VII SMP di Yogyakarta

b. Penelitian ini hanya mampu dilakukan dalam dua siklus karena waktu yang terbatas.

c. Jumlah observer yang terbatas.

\section{Simpulan dan Saran}

Simpulan

Berdasarkan hasil penelitian dan pembahasan yang telah dijelaskan sebelumnya, peneliti dapat menyimpulkan bahwa pembelajaran dengan teknik think-pair-share dapat mengurangi kecemasan matematika siswa SMP yang dibuktikan dengan adanya hasil rekap data angket kecemasan dari kondisi awal, akhir siklus I dan akhir siklus II. Rata-rata kecemasan siswa pada kondisi awal sebesar 90,26 (Tinggi), kemudian menurun menjadi 85 (Tinggi) pada siklus I dan 73 (Sedang) di akhir siklus II. Sedangkan presentase keterlaksanaan pembelajaran pada akhir siklus I sebesar 75,5\% dan pada akhir siklus II sebesar 87\%.

Saran

Beberapa saran dari peneliti untuk guru adalah guru perlu memperhatikan dengan baik langkah-langkah dari metode pembelajaran yang akan diterapkan dan setelah melakukan sebuah pembelajaran maka guru pun perlu melakukan refleksi sebagai proses menjadi guru yang lebih baik lagi. Selain itu, pembelajaran dengan teknik think-pair-share dapat diterapkan untuk aspek afektif lainnya. Pembelajaran yang kooperatif dengan setting dan pelaksanaan yang baik dapat mengurangi rasa kecemasan siswa terhadap matematika.

\section{Daftar Pustaka}

Arends, R. I., \& Kilcher, A. (2010). Teaching for Student Learning Becoming an Accomplished Teacher. Rotledge Taylor \& Francis Group.New York and London.

Ebel,R.L. and Frisbie,D.A. (1991). Essentials of Educational Measurement. $5^{\text {th }}$ Edition, Prentice-Hall, Englewood Cliffs.

Elliot, C. H., \& Smith, L. L. (2006). Anxiety 7 Depression Workbook for Dummies. Indianapolis: Wiley Publishing,Inc.

Haylock, D., \& Thangata, F. (2007). Key concepts in teaching primary mathematics. London: SAGE Publications Ltd.

Kothiyal, A.,dkk. (2013). Effect of Think-Pair-Share in a Large CS1 Class : $83 \%$ Sustained Engagement. International Journal of Educational Technology IIT Bombay, India, (online), (http://www.it.iitb.ac.in/), diakses pada 27 Maret 2018,

J. Dindyal, L. P. Cheng \& S. F. Ng (Eds.). (1993). Mathematics education: Expanding horizons. Proceedings of the 35th annual conference of the Mathematics Education Research Group of Australasia. (pp. 570-577). Singapore: MERGA

Kusuma,Wijaya dan Dedi. (2010). Mengenal Penelitian Tindakan Kelas. Jakarta : PT Index.

M., Puteh, \& S. Z., Khalin. (2016). Mathematics Anxiety and Its Relationship with the Achievement of Secondary Students in Malaysia. International Journal of Social Science and Humanity, 6(2), (pp.119-122). 
Norwood, K. S. (1994). The Effect of Instructional Approach on Mathematics Anxiety and Achievement.School Science and Mathematics. 94(5),(pp. 248-254).

Saputra, P. R. (2014). Kecemasan Matematika Dan Cara Menguranginya ( Mathematic Anxiety and How To Reduce It ). Pythagoras, 3(2), 75-84.

Titsankaew, Pichaya. (2015). The Effects of using Cooperative Learning on Student's Achievement and Attitude toward Mathematics Prosiding The International Conference on Languange, Education, Humanities and Innovation 2015, (pp. 83-87).

Woodard, B. T. (2004). The Effects of Math Anxiety on Post-Secondary Developmental Students as Related to Achievement, Gender, and Age. Inquiry, 9(1), 1-5.

Zakaria, E., \& Nordin, N. M. (2008). The effects of mathematics anxiety on matriculation students as related to motivation and achievement. Eurasia Journal of Mathematics, Science and Technology Education, 4(1), 27-30.

Zeidner, M., \& Matthews, G. (2011). Anxiety 101. New York: Springer Company. 